\title{
Synanthropic rodents and their ectoparasites as carriers of a novel haemoplasma and vector-borne, zoonotic pathogens indoors
}

\author{
Sándor Hornok ${ }^{1 *}$, Gábor Földvári ${ }^{1}$, Krisztina Rigó ${ }^{3}$, Marina L Meli ${ }^{2}$, Enikő Gönczi ${ }^{2}$, Attila Répási ${ }^{3}$, Róbert Farkas ${ }^{1}$,
} Ibolya Papp ${ }^{4}$, Jenő Kontschán ${ }^{5}$ and Regina Hofmann-Lehmann ${ }^{2}$

\begin{abstract}
Background: Despite their close association with human dwellings, the role of synanthropic rodents in the epidemiology of vector-borne infections is seldom studied. The aim of the present study was to compensate for this lack of information, by the molecular investigation of vector-borne bacteria in peridomestic rodents and their ectoparasites.

Findings: Fifty-two rodents (mainly house mice and brown rats) were caught alive in buildings and checked for blood-sucking ectoparasites; followed by molecular analysis of these, together with spleen samples, for the presence of vector-borne agents. Haemoplasma infection was significantly more prevalent among brown rats, than among house mice. A novel haemoplasma genotype (with only 92-93\% similarity to Candidatus Mycoplasma turicensis and M. coccoides in its 165 rRNA gene) was detected in a harvest mouse and a brown rat. Sporadic occurrence of Rickettsia helvetica, Anaplasma phagocytophilum, Borrelia burgdorferi s.l. and Bartonella sp. was also noted in rodents and/or their ectoparasites.
\end{abstract}

Conclusions: These results indicate that synanthropic rodents, although with low prevalence, may carry zoonotic and vector-borne pathogens indoors.

Keywords: Mouse, Rat, Rickettsia, Anaplasma, Borrelia, Bartonella, Haemoplasma

\section{Findings}

\section{Background}

Owing to the number of their species, mice and rats belong to the largest family (Muridae) and order (Rodentia) of mammals. Most rodent species may reach large individual numbers in a wide range of habitats, justifying their epidemiological significance as reservoirs and hosts of pathogens. Among these pathogens, particularly those have received scientific attention during the past few years, which are transmitted by blood-sucking arthropod vectors [1-3].

Ticks are regarded as the most important vectors of disease agents in the temperate zone [4]. However, synanthropic rodents, such as the house mouse (Mus musculus)

\footnotetext{
*Correspondence: hornok.sandor@aotk.szie.hu

'Department of Parasitology and Zoology, Faculty of Veterinary Science, Szent István University, Budapest, Hungary

Full list of author information is available at the end of the article
}

and the brown rat (Rattus norvegicus), which live in or near human dwellings and animal keeping facilities, are usually not tick-infested [2]. Consequently, they are considered to be less important reservoirs of tick-borne pathogens, and seldom evaluated in this respect. Similarly, some hemisynanthropic rodents (living on crops), such as the harvest mouse (Micromys minutus), also less frequently harbor ticks, although they are partly sympatric with more frequently tick-infested rodent species [2]. Nevertheless, even these (hemi)synanthropic rodents are known to have blood-sucking ectoparasites, such as fleas or mites $[1,5]$, which are not host-specific and thus may suck blood on humans e.g. if their primary host dies [6,7]. However, information on the pathogens carried by ectoparasites of synanthropic rodents is scarce, partly because during relevant surveys house mice and brown rats are usually caught with traps that kill them and will cause loss 
of ectoparasites before they could be collected for molecular analyses.

Taken together, ectoparasite communities and associated (zoonotic) pathogens of various wildlife rodent species represent a well-studied issue [8,9], but in this context much less is known about synanthropic rodents (although these could be more relevant to assess from the point of view of zoonotic vector-borne pathogens). Therefore, the present study was undertaken to elucidate if (hemi)synanthropic rodents and their blood-sucking ectoparasites are infected with five important categories of vector-borne pathogens (haemoplasmas, rickettsiae, Anaplasmataceae, Borrelia burgdorferi sensu lato [s.l.] and bartonellae), all including zoonotic agents.

\section{Methods}

\section{Sample collection}

In the present study 52 rodents were collected on ten locations near the north-eastern and southern border of Hungary in 2011. Live catch traps for mice and rats (Nortene, Capital Gardens Ltd., England) were installed in farm buildings and houses. During anaesthesia all small mammals were scrutinized for the presence of ectoparasites which were removed with flea combs or brushes onto white paper. After euthanasia a fraction of the spleen was removed and stored frozen at $-20^{\circ} \mathrm{C}$.

Fleas and lice were identified on the species level according to standard morphological keys. Mites were treated with lactic acid for transparency and their genera/species determined according to [10]. Ectoparasites of the same species collected from the same host were stored (in 70\% ethanol) and processed together.

\section{Molecular analyses}

DNA was extracted individually or in pools (Table 1) according to [11]. The quality and quantity of DNA was assessed by an $18 \mathrm{~S}$ rRNA gene TaqMan real-time PCR [12]. Molecular analyses for rickettsiae, A. phagocytophilum, Borrelia burgdorferi s.l. and bartonellae were performed with TaqMan real-time PCRs as reported [12-15]. The presence of Anaplasmataceae was evaluated with the methods described in [16].

General screening for haemoplasma DNA was done with a SYBR Green real-time PCR [17], and positive samples were then tested with two haemoplasma groupspecific TaqMan real-time PCRs (haemofelis vs. haemominutum groups: [18]). From all samples, yielding threshold cycle $(\mathrm{Ct})$ values below 30 in the group-specific assay, cloning and sequencing was attempted repeatedly as reported [19]. New sequences were submitted to the GenBank.

All PCRs were run while including appropriate positive and negative controls. Phylogenetic analysis was performed with the MEGA 6.06 program by using the neighbor-joining method with maximum composite likelihood model and 1000 bootstrap resamplings [20].

\section{Statistical analysis}

Prevalence data were compared with Fisher's exact test [21], and differences were considered significant when $\mathrm{P}<0.05$.

\section{Ethical approval}

Animals were captured, handled and euthanized while observing the regulations on animal welfare (28/1998).

\section{Results and discussion}

Altogether 51 synanthropic rodents were collected (37 house mice and 14 brown rats), as well as one individual of a hemisynanthropic species (harvest mouse). Their ectoparasites included fleas and mites on ten and three mice, respectively, as well as lice on two rats (Table 1). No ticks were found. The latter result is consistent with previously published data [2], confirming that synanthropic rodents are seldom parasitized by ixodid ticks.

Results of molecular analyses are shown in Table 1. In the category of haemotropic Mycoplasma spp. (haemoplasmas) only members of the haemofelis group were detected. This is not surprising in light of the fact that both known murine haemoplasmas (M. haemomuris and M. coccoides) represent this category [18]. Haemoplasma infection was significantly $(\mathrm{P}=0.019)$ more prevalent among rats, than mice. Haemoplasmas were detected in blood-sucking lice, but not in mites and fleas of PCR positive rodents, in line with the known vector competence of Polyplax spinulosa [22,23]. Sequencing of the PCR product from the harvest mouse spleen DNA sample revealed a novel haemoplasma genotype (KC863983), exhibiting the closest, but only $93 \%$ homology to Candidatus M. turicensis (DQ157152) and M. coccoides (AY171918) (Figure 1). Interestingly, a similar genotype (having 98\% sequence homology to the above novel haemoplasma, but only $92 \%$ and $93 \%$ to $M$. coccoides and Candidatus $\mathrm{M}$. turicensis, respectively) was identified in a rat spleen sample (KJ739311). Phylogenetically the two genotypes of this novel haemoplasma represent a separate cluster from both formerly known murine haemoplasmas (Figure 1). In addition, a haemoplasma sequence highly (99\%) similar to a Japanese rat Mycoplasma sp. isolate (AB752303, [24]) was recovered from another rat (KJ739312, Figure 1). Concerning the potential medicalepidemiological implications of these findings, while rodent haemoplasmas are not known to be zoonotic per se, the recently discovered human haemotropic Mycoplasma species (C. Mycoplasma haemohominis) is genetically most closely related to these haemoplasmas [25] (Figure 1). 
Table 1 Pathogens and endosymbionts detected in the spleen and ectoparasites of synanthropic and hemisynanthropic rodents

\begin{tabular}{|c|c|c|c|c|c|c|c|c|c|c|}
\hline \multirow[t]{3}{*}{ Host species } & \multirow[t]{3}{*}{ Sample type } & \multirow{3}{*}{$\begin{array}{l}\text { Number of } \\
\text { specimens } \\
\text { per animal }\end{array}$} & \multirow{3}{*}{$\begin{array}{l}\text { Total } \\
\text { number of } \\
\text { samples } \\
\text { analysed }\end{array}$} & \multicolumn{7}{|c|}{ PCR positives/all tested } \\
\hline & & & & \multicolumn{2}{|c|}{ Haemotropic Mycoplasma spp. } & \multicolumn{3}{|c|}{ Rickettsiales } & \multicolumn{2}{|l|}{ Others } \\
\hline & & & & $\begin{array}{l}\text { Haemofelis } \\
\text { group }\end{array}$ & Result of sequencing & $\begin{array}{l}\text { Rickettsia } \\
\text { helvetica }\end{array}$ & $\begin{array}{l}\text { Anaplasma } \\
\text { phagocytophilum }\end{array}$ & Wolbachia sp. & $\begin{array}{l}\text { Borrelia } \\
\text { burgdorferi s.l. }\end{array}$ & Bartonella sp. \\
\hline \multirow[t]{3}{*}{ Mus musculus } & spleen & 1 & 37 & $21 / 37$ & not successful & $1 / 37$ & & & $1 / 37$ & \\
\hline & flea (Leptopsylla segnis) & $1-3$ & 10 & & - & $2 / 10$ & & $1 / 10$ & & $1 / 10$ \\
\hline & mite (Laelaps algericus) & $1-15$ & 3 & & - & $1 / 3$ & $1 / 3$ & & & \\
\hline Micromys minutus & spleen & 1 & 1 & $1 / 1$ & nM. sp. $(1 \times, 100 \%)$ & & & & & \\
\hline \multirow[t]{2}{*}{ Rattus norvegicus } & spleen & 1 & 14 & $13 / 14$ & $\begin{array}{l}\text { nM. sp. }(1 \times, 98 \%), \text { M. sp. } \\
{\left[\text { AB752303] }(1 \times, 99 \%)^{*}\right.}\end{array}$ & & & & $1 / 14$ & \\
\hline & louse (Polyplax spinulosa) & $4-50$ & 2 & $1 * / 2$ & - & & & & & \\
\hline
\end{tabular}

Abbreviation: (n)M. sp. - (novel) Mycoplasma species.

One pool contained all ectoparasites of the same species removed from one host individual. All samples were tested for all pathogens shown, but only positive results are indicated. PCR positivity of corresponding samples (ectoparasites and their host) are marked with asterisk $(*)$. 


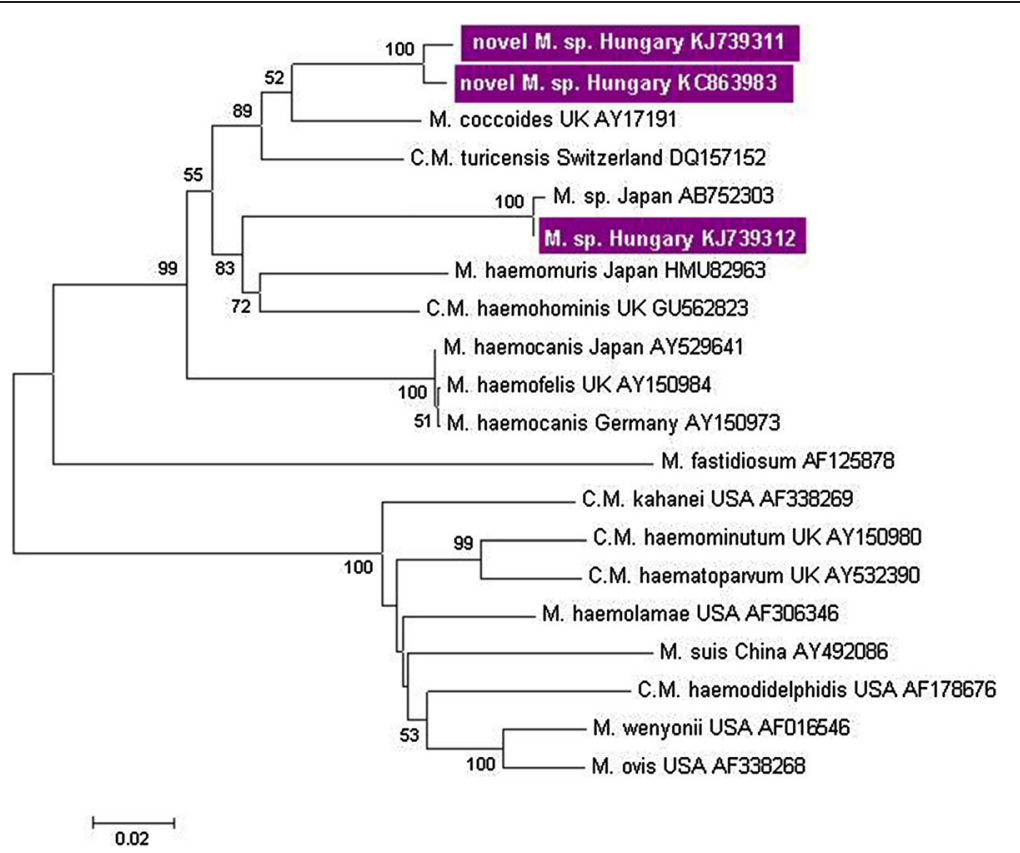

Figure 1 Phylogenetic relationships of the haemoplasma isolates found in the present study with other species of the category. Branch lengths correlate to the number of substitutions inferred according to the scale shown.

In the category of rickettsial agents, Rickettsia helvetica was present in one house mouse, and in fleas/mites of three further house mice (Table 1). Although this zoonotic, potentially pathogenic bacterium is known to occur in wildlife rodents and their ectoparasites [26], it was (to the best of our knowledge) hitherto unreported in house mouse and its fleas or mites. No other rickettsiae were found.

Anaplasma phagocytophilum was detected in mouse mites (Table 1). This zoonotic pathogen has already been reported from laelapid mites from wild rodents [5], but this appears to be its first finding in Laelaps algericus of the house mouse.

The epidemiological significance of these data is provided by the fact that both fleas and mites of rodents are known to feed on man [6,7]. Rodent fleas are competent vectors of rickettsiae other than $R$. helvetica [26], and non-tick acarines can potentially transmit $A$. phagocytophilum [5].

In addition, a sequence (KC852875) with the closest (98\%) homology to Wolbachia sp. endosymbionts (e.g. AB746399) was identified in the mouse flea (Table 1).

Borrelia burgdorferi s.l., including the causative agents of Lyme disease in animals and humans, was also detected in one house mouse and one brown rat (Table 1), but in none of the ectoparasites. These results improve the paucity of data on the occurrence of borreliae in these two rodent species $[27,28]$. Despite being a principally tick-borne group of pathogens, B. burgdorferi s.l. was reported to be potentially transmitted by rodent mites [29]. Correspondingly, it is not unexpected to find PCR-positive rodents in the absence of tick-infestation (as reported here), although previous exposure to ticks in the present case cannot be ruled out.

Finally, Bartonella sp. positivity was detected for the first time in the flea Leptopsylla segnis from a mouse (Table 1), corroborating previous finding of bartonellae in the same flea species from rats [30]. In this context it is relevant to note that fleas are regarded as competent vectors of Bartonella spp. [31], which are known to occur in both wild and urbanized rodents [32,33].

Except for the mutual haemoplasma positivity of one rat and its lice, the PCR status of vectors did not correspond to that of their host (i.e. in most cases PCR positive ectoparasites were found on PCR negative hosts, and vice versa). This suggests that the evaluated rodent species or their ectoparasites (albeit with low prevalence) could become prolonged carriers of relevant pathogens, increasing the epidemiological significance of the present findings.

\section{Conclusions}

In summary, genetic data are provided here for the first time on the existence of a novel rodent haemoplasma. Results of the molecular analyses in this study also compensate for the scarcity of information on the epidemiological significance of synanthropic rodents and their blood-sucking ectoparasites. The majority of detected pathogens ( $R$. helvetica, A. phagocytophilum and Borrelia burgdorferi s.l.) are transmitted by ticks, in Europe by 
Ixodes ricinus. Although the present results confirm that synanthropic rodents are seldom tick infested, they or their ectoparasites can still harbor tick-borne, zoonotic pathogens indoors.

\section{Competing interests}

The authors declare that they have no competing interests.

\section{Authors' contributions}

$\mathrm{SH}$ collected the ectoparasites, extracted the DNA and has written the manuscript. GF was in charge of mouse collection and instructed KR. KR and EG performed the molecular analyses. RF supervised parasitological work. AR and IP contributed significantly to rat collection. JK identified the mites. MM designed, and in part performed the molecular analyses. RH-L initiated and supervised the study. All authors read and approved the final version of the manuscript.

\section{Acknowledgments}

The authors would like to thank the contributions of S. Kovalcsik, A. Lépold, G. Gyenes and M. Reisinger (Reinvo Kft.) to the present results. Sándor Hornok and Gábor Földvári were supported by the János Bolyai Research Scholarship of the Hungarian Academy of Sciences. Molecular work was partially performed using the logistics of the Center for Clinical Studies at the Vetsuisse Faculty of the University of Zurich.

\section{Author details}

${ }^{1}$ Department of Parasitology and Zoology, Faculty of Veterinary Science, Szent István University, Budapest, Hungary. ${ }^{2}$ Clinical Laboratory and Center for Clinical Studies, Vetsuisse Faculty, University of Zurich, Zurich, Switzerland. ${ }^{3}$ County Veterinary Station, Borsod-Abaúj-Zemplén, Miskolc, Hungary. ${ }^{4}$ Veterinary Clinic, Mohács, Hungary. ${ }^{5}$ Plant Protection Institute, Centre of Agricultural Research of Hungarian Academy of Sciences, Budapest, Hungary.

Received: 8 May 2014 Accepted: 30 December 2014 Published online: 15 January 2015

\section{References}

1. Fleer KA, Foley P, Calder L, Foley JE. Arthropod vectors and vector-borne bacterial pathogens in Yosemite National Park. J Med Entomol. 2011;48:101-10.

2. Mihalca AD, Dumitrache MO, Sándor AD, Magdaş C, Oltean M, Györke A, et al. Tick parasites of rodents in Romania: host preferences, community structure and geographical distribution. Parasit Vectors. 2012;5:266.

3. Helhazar M, Leitão J, Duarte A, Tavares L, da Fonseca IP. Natural infection of synathropic rodent species Mus musculus and Rattus norvegicus by Leishmania infantum in Sesimbra and Sintra-Portugal. Parasit Vectors. 2013;6:88.

4. Jongejan F, Uilenberg G. The global importance of ticks. Parasitology. 2004;129(Suppl):S3-14.

5. Reeves WK, Dowling AP, Dasch GA. Rickettsial agents from parasitic dermanyssoidea (Acari: Mesostigmata). Exp Appl Acarol. 2006;38:181-8

6. Li Z-I, Xio B-I. Observations on the breeding and biological characteristics of Leptopsylla segnis. Endem Dis Bull. 1993;8:26-8.

7. Robinson WH. Urban insects and Arachnids. Cambridge, UK: Cambridge University Press; 2005. p. 397.

8. Durden LA, Polur RN, Nims T, Banks CW, Oliver Jr JH. Ectoparasites and other epifaunistic arthropods of sympatric cotton mice and golden mice: comparisons and implications for vector-borne zoonotic diseases. J Parasitol. 2004;90:1293-7.

9. Stevenson HL, Bai Y, Kosoy MY, Montenieri JA, Lowell JL, Chu MC, et al. Detection of novel Bartonella strains and Yersinia pestis in prairie dogs and their fleas (Siphonaptera: Ceratophyllidae and Pulicidae) using multiplex polymerase chain reaction. J Med Entomol. 2003;40:329-37.

10. Masán P, Fenda P. A review of the laelapid mites associated with terrestrial mammals in Slovakia, with a key to the European species (Acari: Mesostigmata: Dermanyssoidea). Bratislava, Slovakia: Slovak Academy of Sciences; 2010. p. 188.

11. Hornok S, Kováts D, Csörgő T, Meli ML, Gönczi E, Hadnagy Z, et al. Birds as potential reservoirs of tick-borne pathogens: first evidence of bacteraemia with Rickettsia helvetica. Parasit Vectors. 2014;7:128.
12. Boretti FS, Perreten A, Meli ML, Cattori V, Willi B, Wengi N, et al. Molecular investigations of Rickettsia helvetica infection in dogs, foxes, humans and Ixodes spp. ticks. Appl Environ Microbiol. 2009;75:3230-7.

13. Pusterla N, Huder JB, Leutenegger CM, Braun U, Madigan JE, Lutz H. Quantitative real-time PCR for detection of members of the Ehrlichia phagocytophila genogroup in host animals and Ixodes ricinus ticks. J Clin Microbiol. 1999;37:1329-31.

14. Leutenegger CM, Pusterla N, Mislin CN, Weber R, Lutz H. Molecular evidence of coinfection of ticks with Borrelia burgdorferi sensu lato and the human granulocytic ehrlichiosis agent in Switzerland. J Clin Microbiol. 1999;37:3390-1.

15. Molia S, Chomel BB, Kasten RW, Leutenegger CM, Steele BR, Marker L, et al. Prevalence of Bartonella infection in wild African lions (Panthera leo) and cheetahs (Acinonyx jubatus). Vet Microbiol. 2004;100:31-41.

16. Hornok S, Földvári G, Elek V, Naranjo V, Farkas R, de la Fuente J. Molecular identification of Anaplasma marginale and rickettsial endosymbionts in blood- sucking flies (Diptera: Tabanidae, Muscidae) and hard ticks (Acari: Ixodidae). Vet Parasitol. 2008;154:354-9.

17. Willi B, Meli ML, Lüthy R, Honegger H, Wengi N, Hoelzle LE, et al. Development and application of a universal hemoplasma screening assay based on the SYBR green PCR principle. J Clin Microbiol. 2009;47:4049-54.

18. Tasker S, Peters IR, Mumford AD, Day MJ, Gruffydd-Jones TJ, Day S, et al. Investigation of human haemotropic Mycoplasma infections using a novel generic haemoplasma qPCR assay on blood samples and blood smears. J Med Microbiol. 2010;59(Pt 11):1285-92.

19. Hornok S, Meli ML, Perreten A, Farkas R, Willi B, Beugnet F, et al. Molecular investigation of hard ticks (Acari: Ixodidae) and fleas (Siphonaptera: Pulicidae) as potential vectors of rickettsial and mycoplasmal agents. Vet Microbiol. 2010;140:98-104.

20. Tamura K, Peterson D, Peterson N, Stecher G, Nei M, Kumar S. MEGA5: Molecular evolutionary genetics analysis using maximum likelihood, evolutionary distance, and maximum parsimony methods. Mol Biol Evol. 2011;28:2731-9.

21. Rózsa L, Reiczigel J, Majoros G. Quantifying parasites in samples of hosts. J Parasitol. 2000;86:228-32.

22. Neimark H, Johansson KE, Rikihisa Y, Tully JG. Proposal to transfer some members of the genera Haemobartonella and Eperythrozoon to the genus Mycoplasma with descriptions of 'Candidatus Mycoplasma haemofelis', 'Candidatus Mycoplasma haemomuris', 'Candidatus Mycoplasma haemosuis' and 'Candidatus Mycoplasma wenyonii'. Int J Syst Evol Microbiol. 2001;51(Pt 3):891-9.

23. Neimark H, Peters W, Robinson BL, Stewart LB. Phylogenetic analysis and description of Eperythrozoon coccoides, proposal to transfer to the genus Mycoplasma as Mycoplasma coccoides comb. nov. and Request for an Opinion. Int J Syst Evol Microbiol. 2005;55(Pt 3):1385-91.

24. Sashida H, Sasaoka F, Suzuki J, Watanabe Y, Fujihara M, Nagai K, et al. Detection of hemotropic mycoplasmas in free-living brown sewer rats (Rattus norvegicus). J Vet Med Sci. 2013;75:979-83.

25. Steer JA, Tasker S, Barker EN, Jensen J, Mitchell J, Stocki T, et al. A novel hemotropic Mycoplasma (hemoplasma) in a patient with hemolytic anemia and pyrexia. Clin Infect Dis. 2011;53:e147-51.

26. Sprong $H$, Wielinga PR, Fonville $M$, Reusken $C$, Brandenburg AH, Borgsteede F, et al. Ixodes ricinus ticks are reservoir hosts for Rickettsia helvetica and potentially carry flea-borne Rickettsia species. Parasit Vectors. 2009;2:41.

27. Burgess EC, Wachal MD, Cleven TD. Borrelia burgdorferi infection in dairy cows, rodents, and birds from four Wisconsin dairy farms. Vet Microbiol. 1993;35:61-77.

28. Masuzawa T, Hashimoto N, Kudeken M, Kadosaka T, Nakamura M, Kawabata $\mathrm{H}$, et al. New genomospecies related to Borrelia valaisiana, isolated from mammals in Okinawa archipelago, Japan. J Med Microbiol. 2004;53(Pt 5):421-6.

29. Netusil J, Zákovská A, Horváth R, Dendis M, Janouskovcová E. Presence of Borrelia burgdorferi sensu lato in mites parasitizing small rodents. Vector Borne Zoonotic Dis. 2005;5:227-32.

30. Loftis AD, Reeves WK, Szumlas DE, Abbassy MM, Helmy IM, Moriarity JR, et al. Surveillance of Egyptian fleas for agents of public health significance: Anaplasma, Bartonella, Coxiella, Ehrlichia, Rickettsia, and Yersinia pestis. Am J Trop Med Hyg. 2006;75:41-8.

31. Bown KJ, Bennet M, Begon M. Flea-borne Bartonella grahamii and Bartonella taylorii in bank voles. Emerg Infect Dis. 2004;10:684-7. 
32. Telfer S, Clough HE, Birtles LR, Bennett M, Carslake D, Helyar S, et al. Ecological differences and coexistence in a guild of microparasites: bartonella in wild rodents. Ecology. 2007:88:1841-9.

33. Harrus S, Bar-Gal GK, Golan A, Elazari-Volcani R, Kosoy MY, Morick D, et al. Isolation and genetic characterization of a Bartonella strain closely related to Bartonella tribocorum and Bartonella elizabethae in Israeli commensal rats. Am J Trop Med Hyg. 2009;81:55-8.

Submit your next manuscript to BioMed Central and take full advantage of:

- Convenient online submission

- Thorough peer review

- No space constraints or color figure charges

- Immediate publication on acceptance

- Inclusion in PubMed, CAS, Scopus and Google Scholar

- Research which is freely available for redistribution 